\title{
Desain dan Implementasi Sistem Visible Light Communication berbasis Pulse Width Modulation
}

\author{
Angga Pradana ${ }^{1}$, Syifaul Fuada ${ }^{2}$, Trio Adiono ${ }^{3}$
}

\begin{abstract}
The design, implementation, and its evaluation of visible light communication (VLC) system using single pulse width modulation (1-PWM) is presented in this paper. The designed system consists of two primary blocks: VLC Coordinator that covers digital signal processing (DSP) device and analog front-end (AFE) transmitter whereas the VLC client covers the DSP device and AFE receiver. The Microcontroller STM32F4 development board was employed as the DSP device in this work, it was used for coordinator- and client-side. The VLC demo shows that real-time texts streaming with $10 \mathrm{~kb}$ of packet size can be performed well. Our VLC system can be used optimally in 50 to $70 \mathrm{~cm}$ of optical channel distance with 0 degrees. In other hands, the maximum bit-rate of this VLC system is limited to $3.3 \mathrm{kbps}$.
\end{abstract}

Intisari- Desain, implementasi, dan pengujian sistem komunikasi cahaya tampak menggunakan modulasi 1-PWM telah dibahas pada makalah ini. Sistem VLC terdiri atas dua blok utama: VLC coordinator yang meliputi DSP dan AFE transmitter. Sementara VLC client terdiri atas AFE receiver dan DSP receiver. Perangkat DSP pada penelitian ini adalah berbasis Mikrokontroller STM32F4 yang difungsikan untuk modulasidemodulasi. Hasil demonstrasi menunjukkan bahwa streaming konten teks sebesar $10 \mathrm{~kb}$ dapat didemonstrasikan dengan baik. Sistem VLC dapat digunakan dengan optimal pada jarak 50 $70 \mathrm{~cm}$ (sudut $=0^{\circ}$ ). Secara keseluruhan, laju data maksimum yang dicapai adalah $3,3 \mathrm{kbps}$.

Kata Kunci- Komunikasi cahaya tampak, Mikrokontroller STM32F4, PWM, Real-time streaming.

\section{PENDAHULUAN}

Medium bertukar informasi yang paling umum saat ini adalah dengan menggunakan frekuensi radio (RF), seperti Wi-Fi, Bluetooth, NFC, dan ZigBee. Teknologi interkoneksi wireless menggunakan gelombang $\mathrm{RF}$ tersebut memiliki keterbatasan dalam ketersediaan spektrum, selain itu efisiensi energi pancaran gelombang rendah, dan resiko kesehatan yang tinggi, kemudian juga isu tentang sekuritas komunikasi [1]. Sementara komunikasi optik seperti fiber seperti yang dilakukan oleh [2-3] memerlukan medium kabel serat optik untuk transmisi dan komunikasi Infrared rentan terhadap resiko kanker kulit manusia. Baru-baru ini visible light communication (VLC) tengah dikembangkan dan menuju tahap komersialisasi sebagai alternatif komunikasi nirkabel

\footnotetext{
1,2 Peneliti, University Center of Excellence on Microelectronics Institut Teknologi Bandung, Gd. PAU Lt IV, Jl. Tamansari No 126 Kampus ITB, Kota Bandung, Jawa Barat, 40132, INDONESIA; e-mail: syifaulfuada@pme.itb.ac.id)

${ }^{3}$ Dosen, STEI ITB, Jln. Ganesha No.10, Gd. LABTEK VIII, 40132, INDONESIA (e-mail: tadiono@stei.itb.ac.id)
}

Angga Pradana: Disain dan Implementasi sistem...
[4]. Berbeda dengan fiber optik, medium VLC ada ruang hampa.

Gagasan dasar dari VLC adalah mentransmisikan data dengan memodulasikan sinyal cahaya tampak menggunakan alat penerangan komersil yang telah tersedia pada infrastruktur dalam ruang (indoor), yakni LED [5] dan fotodetektor dimanfaatkan sebagai penerima sinyal informasi. Semakin tinggi level iluminansi LED maka received power terhadap fotodetektor akan semakin besar dan begitu pula sebaliknya [6].

Sifat cahaya tampak adalah tidak dapat menembus objek padat seperti dinding, dengan demikian VLC adalah media komunikasi yang terbatas dalam area dan arah tertentu dan dianggap sebagai sebuah media komunikasi nirkabel yang lebih aman dari pada RF [7]. Fungsi utama sistem VLC adalah melakukan transmisi data dengan melakukan perubahan tingkat pendaran cahaya (luminaries) yang mana sistem VLC tersebut tidak boleh mempengaruhi fungsionalitas utama dari LED sebagai sumber penerangan dan tidak menimbulkan efek flicker atau blink [8]. Salah satu aspek penting untuk mewujudkan perangkat penerangan sekaligus sebagai perangkat komunikasi adalah pemilihan teknik modulasi yang mana On-Off Keying (OOK) merupakan jenis yang paling populer dimplementasikan pada VLC.

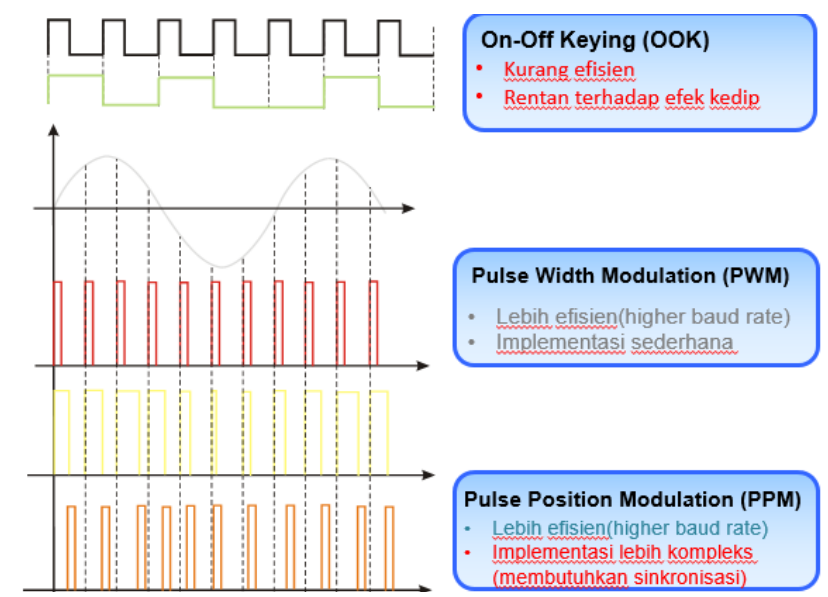

Gambar 1: Modulasi binary level

Gambar 1 merupakan komparasi modulasi OOK dengan modulasi digital lainnya, yakni Pulse Width Modulation (PWM) dan Pulse Position Modulation (PPM) merupakan jenis modulasi yang paling sederhana dimana data ' 0 ' dinyatakan dengan kondisi lampu menyala (on) sedangkan data ' 1 ' direpresentasikan dengan lampu mati (off) atau bisa sebaliknya. Karena data di-encoded dalam dua kondisi saja, maka OOK kurang efisien dalam memanfaatkan bandwidth [9]. Isu lain dalam penggunaan modulasi OOK ini adalah

$$
\text { p-ISSN:1693 - 2951; e-ISSN: 2503-2372 }
$$

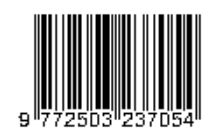


pengaruh terhadap fungsi pencahayaan. Pemanfaatan LED sebagai media komunikasi tidak boleh mengganggu fungsi LED tersebut sebagai sumber pencahayaan. LED tidak boleh mengalami efek blinking dan dimming selama proses komunikasi berlangsung. Pada modulasi OOK, kondisi LED akan sangat bergantung pada data yang akan ditransmisikan, apabila LED driver mendapatkan input berupa deretan data ' 0 ' sebanyak 1 Byte, maka LED akan berada dalam kondisi 'off' dalam waktu yang lebih lama sehingga kemungkinan timbul efek dimming dan blinking terhadap sistem pencahayaan dalam ruangan tersebut. Sementara PPM dan PWM mampu membawa beberapa bit data dalam setiap satu pulsa digital sehingga lebih hemat pemakaian bandwidth dibandingkan dengan OOK dan mampu mengontrol tingkat ilumninasi cahaya LED yang stabil [10]. Namun, implementasi PPM lebih rumit daripada PWM.

Makalah ini merupakan engineering design yang mendiskusikan tentang rancang bangun sistem VLC untuk transmisi data-data rendah dalam real-time dengan modulasi PWM, yakni streaming konten multimedia berupa text.

\section{Metode PerancAngan}

Penelitian ini dikerjakan dalam beberapa tahap yaitu: 1) penentuan spesifikasi; 2) perancangan layer fisik sistem VLC yang terdiri atas digital signal processing (DSP), analog front end (AFE) transceiver, dan Graphic User Interface (GUI) yang terpasang pada komputer yang merupakan lapisan aplikasi; 3) demonstrasi dan evaluasi. Desain DSP mencakup pemilihan jenis modulasi yaitu PWM. Kemudian desain AFE transceiver mencakup LED driver topologi switch dan blok penerima.

\section{A. Spesifikasi Sistem}

VLC yang didesain terdiri atas koordinator dan client dengan topologi komunikasi point-to-point untuk keperluan downlink (satu arah) seperti yang diilustrasikan pada Gambar 2. LED digunakan sebagai antenna sedangkan photodioda digunakan sebagai receiver. Link antara koordinator dan client ini disusun dengan konfigurasi directed line-of-sight (LOS) yakni perangkat penerima dihadapkan langsung dengan pemancar.
Pada bagian koordinator atas dari personal computer (PC), mikrokontroller, rangkaian AFE transmitter yang mencakup LED driver dan LED. Pada bagian client terdiri atas photodetector dan rangkaian $\mathrm{AFE}$ receiver, mikrokontroller dan PC. Jenis LED yang digunakan adalah high-brightness LED (HBLED) tunggal dengan daya tinggi dan warna putih karena warna ini sesuai digunakan sebagai sarana penerangan ruangan dibandingkan warna lain. Daya HBLED yang dipilih adalah maksimum 10 Watt sehingga dapat digunakan untuk berkomunikasi setidaknya dalam jarak 1 - 1,5 meter dan tetap aman untuk mata manusia. Sementara photodetector yang dipilih sebagai receiver adalah photodioda karena karena memiliki respon waktu yang paling cepat dibandingkan jenis photodetector lain seperti Light Dependent Resistor (LDR) dan phototransistor. Untuk menjamin realisasi infrastruktur VLC yang low-cost, maka Op-Amp general purpose digunakan sebagai analog signal processing kecuali pada blok trans-impedance amplifier (TIA) yang memakai specific OP-AMP. Tabel I merupakan spesifikasi dari komponen yang digunakan.

TABEL I

SPESIFIKASI TEKNIS HBLED, PHOTODIODE, DAN OP-AMP

\begin{tabular}{|c|c|}
\hline Komponen & Spesifikasi \\
\hline \multirow{7}{*}{ HBLED } & Model: Coo Chip LEDMD-W110C \\
\hline & Produksi: Hyrite Lighting.co \\
\hline & Tegangan Kerja: $12 \mathrm{~V}_{\mathrm{DC}}$ \\
\hline & Daya: 9 Watt (maks.) \\
\hline & Sudut pancaran: $178^{\circ}$ \\
\hline & Intensitas cahaya: 550 lumen \\
\hline & $\lambda: 380-760 \mathrm{~nm}$ \\
\hline \multirow{5}{*}{ Photodiode } & Model: SP-8ML \\
\hline & Produksi: Kodenshi. Corp \\
\hline & Luas penampang efektif $\left(A_{r}\right): 7,4 \mathrm{~mm}^{2}$ \\
\hline & $\lambda: 450-1050 \mathrm{~nm}$ \\
\hline & short circuit/ $I_{S C}: 270 \mu \mathrm{A}$ saat $1000 \mathrm{lux}$ \\
\hline \multirow{3}{*}{$\begin{array}{l}\text { OP-AMP } \\
\text { general } \\
\text { purpose }\end{array}$} & Model: LM358 \\
\hline & Produksi: Texas Instrument.Inc \\
\hline & Gain bandwidth Product: $1 \mathrm{MHz}(\mathrm{G}=1 \mathrm{kali})$ \\
\hline \multirow{4}{*}{$\begin{array}{l}\text { OP-AMP } \\
\text { specific } \\
\text { purpose }\end{array}$} & Model: AD8011AN \\
\hline & Produksi: Analog Devices.Inc \\
\hline & Gain bandwidth Product: $300 \mathrm{MHz}(\mathrm{G}=1 \mathrm{kali})$ \\
\hline & Riselfall time: $0,4 \mathrm{~ns}$ \\
\hline
\end{tabular}

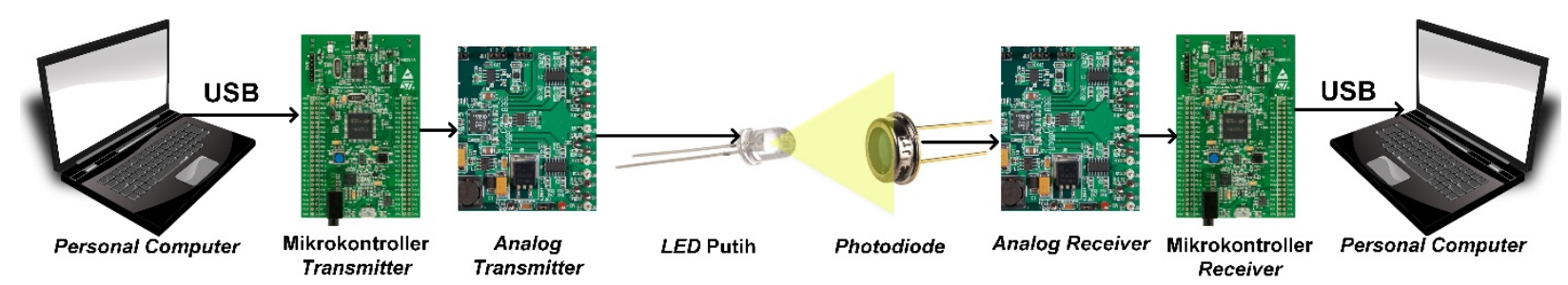

Gambar 1: Blok sistem VLC

Modulasi yang dipakai adalah PWM dengan pertimbangan karena mampu membawa lebih banyak bit dibandingkan OOK. PWM diimplementasikan pada modul mikrokontroller STM32F4 discovery yang merupakan suatu development board dengan mikrokontroller Advanced RISC Machine (ARM)
Cortex M4 [11]. Kecepatan clock dari chip STM32F407 maksimum adalah mampu mencapai $168 \mathrm{MHz}$ sehingga ketika dipakai untuk samping ADC data-data kecil seperti teks, sudah cukup memadahi

\section{B. Desain PWM}


Pada skema modulasi PWM, data direpresentasikan dengan duty cycle (D) seperti ditunjukkan pada Gambar 3(c). Dengan memvariasikan lebar dan posisi pulsa, jenis modulasi PWM mampu membawa multi-bit data pada setiap periode simbolnya. Dalam hal ini, untuk membawa 2 bit data per periode simbol pada modulasi PWM, maka diperlukan empat duty cycle level, yakni $\mathrm{D}_{1}, \mathrm{D}_{2}, \mathrm{D}_{3}, \mathrm{D}_{4}$, dan empat level posisi $\mathrm{T}_{1}, \mathrm{~T}_{2}, \mathrm{~T}_{3}, \mathrm{~T}_{4}$.

(a)

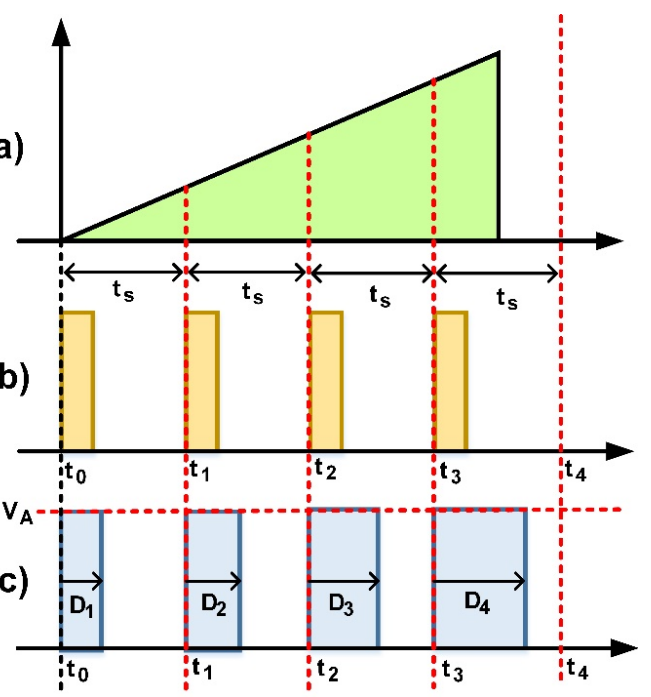

Gambar 3: Sinyal pulsa dari PWM: (a) Data analog terkuantisasi 2 bit (b) pulsa sampling; (c) pulsa PWM, Gambar direproduksi ulang dari [8]

Karena duty cycle pada PWM bergantung terhadap data yang akan dikirim, maka tegangan rata-rata pada pulsa PWM akan menjadi fluktuatif yang dapat direpresentasikan pada persaman (1). Saat D.T $<\mathrm{t}<\mathrm{T}$, maka akan menjadi persamaan (2). Apabila PWM digunakan untuk memodulasi data digital 1 bit, maka untuk membedakan data ' 0 ' dan data ' 1 ' adalah dengan memvariasikan nilai D namun nilai $\mathrm{D}$ tersebut harus dipilih cukup lebar ketika diimplementasikan pada sistem VLC sehingga noise margin tinggi dan harus cukup sempit sehingga tidak menimbulkan efek dimming terhadap fungsi pencahayaan.

Implementasi modulasi PWM dalam board mikrokontroller STM32F4 disajikan pada lampiran makalah ini tentang source code untuk fungsi encoding dan decoding.

$\overline{\mathrm{v}}=\frac{1}{\mathrm{~T}} \int_{0}^{\mathrm{T}} \mathrm{v}(\mathrm{t}) \mathrm{dt}$

$\overline{\mathrm{v}}=\mathrm{D} \cdot \mathrm{v}_{\text {max }}+(1-\mathrm{D}) \mathrm{v}_{\text {min }}$

\section{Tegangan Kerja LED}

Kurva karakteristik hubungan antara tegangan (forward voltage) dengan arus (forward current) dari HBLED produk Hyrite Coo Chip yang digunakan dalam Angga Pradana: Disain dan Implementasi sistem... 2503-2372 penelitian ini ditunjukkan pada Gambar 4. Dari grafik dapat diperhatikan bahwa bahwa LED mulai menyala (turn-on condition) idealnya pada tegangan $7,8 \mathrm{~V}_{\mathrm{DC}}$ minimum dan maksimum pada $10,3 \mathrm{~V}_{\mathrm{DC}}$. Informasi ini dapat diperoleh dengan melihat pada datasheet atau karakterisasi sendiri dengan eksperimen untuk mencari hubungan keduanya [12-13]. Data karakteristik ini dijadikan acuan dalam merancang LED driver.

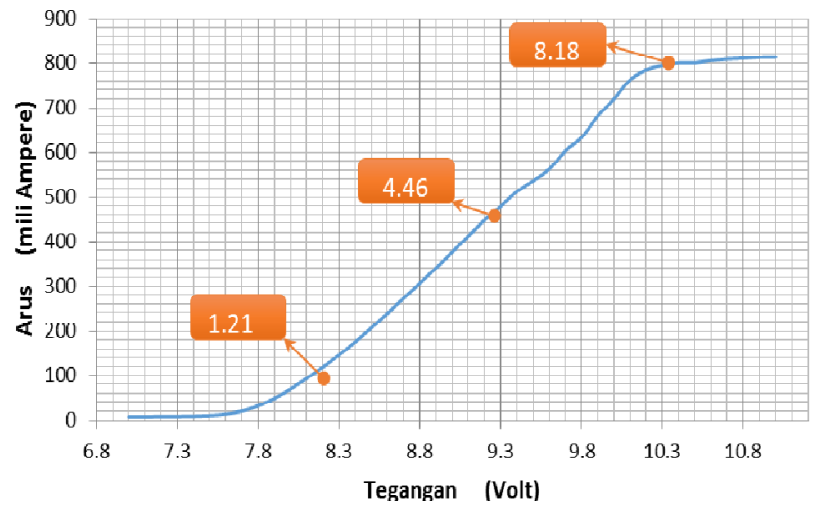

Gambar 4: Kurva hubungan tegangan (V) terhadap arus (mA) dari modul HBLED Coo Chip MD-W110C

\section{Desain Modul AFE transmitter}

Modulasi PWM merepresentasikan angka ' 1 ' dan '0' sehingga LED driver yang sesuai adalah jenis switch karena hanya mengkondisikan menyala (on) dan padam (off) saja [14]. Rancangan switch LED driver ditunjukkan pada Gambar 5 yang mana terdiri atas dua transistor. Transistor BJT Q1 (2N222) digunakan untuk menguatkan tegangan keluaran mikrokontroller STM32F4. Sementara transistor MOSFET Q2 (IRFZ44N) digunakan untuk menguatkan arus. Rangkaian LED driver dirancang sedemikian rupa sehingga memiliki prinsip kerja sebagai berikut: ketika kondisi LED menyala, maka sinyal digital termodulasi akan menghasilkan logika '0", begitu pula sebaliknya.

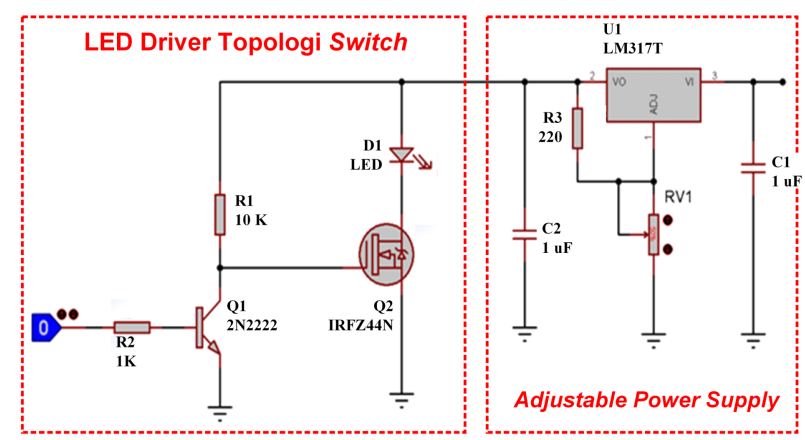

Gambar 5: Rangkaian LED driver dan power supply

Untuk keperluan pengujian, maka rangkaian LED driver untuk modulasi PWM ini dilengkapi dengan

p-ISSN:1693 - 2951; e-ISSN: 
sumber tegangan variabel sehingga level iluminasi HBLED dapat divariasikan dari kondisi sangat terang ke kondisi sebaliknya. Komponen utama sumber tegangan variabel ini adalah U2 (IC LM317) yang merupakan regulator tegangan yang dapat disetel tegangan keluarannya. Berdasarkan grafik pada Gambar 4, maka dapat disimpulkan bahwa tegangan kerja efektif dari LED ini berkisar antara 7,8 - 10,3 $\mathrm{V}_{\mathrm{DC}}$. Kemudian, $\mathrm{V}_{\text {out }}$ dari LM317 dapat diubah dengan mengatur resistansi $\mathrm{RV}_{1}$ sesuai persamaan (3).

$\mathrm{V}_{\mathrm{o}}=\mathrm{V}_{\mathrm{ref}}\left(1+\frac{\mathrm{RV}}{\mathrm{R}_{3}}\right)+\mathrm{I}_{\mathrm{adj}} \mathrm{RV}_{1}$

Pada umumnya nilai $\mathrm{V}_{\text {ref }}=1,25 \mathrm{~V}_{\mathrm{DC}}$ dan $\mathrm{I}_{\mathrm{adj}}=50$ $\mu A$. Dengan mengacu pada persamaan (3), apabila dipilih nilai $\mathrm{R}_{3}=470 \Omega$, maka untuk mengeluarkan tegangan kerja minimum dari HBLED sebesar 7,8 $\mathrm{V}_{\mathrm{DC}}$ nilai RV1 adalah 2,52 $\mathrm{k} \Omega$. Sedangkan untuk mengeluarkan tegangan kerja maksimum dari LED sebesar $10,3 \mathrm{~V}_{\mathrm{DC}}$, maka nilai $\mathrm{RV}_{1}$ adalah $3,34 \mathrm{~V}_{\mathrm{DC}}$.

\section{E. Desain Modul AFE Receiver}

AFE receiver terdiri atas beberapa blok, pertama adalah TIA yang berfungsi sebagai $I-V$ converter, yakni mengubah arus photodiode $\left(I_{P D}\right)$ menjadi tegangan $\left(\mathrm{V}_{\mathrm{TIA}}\right)$ [15]. Selanjutnya Pre-amplifier sebagai penguat tegangan tahap pertama karena amplitude dari $\mathrm{V}_{\mathrm{TIA}}$ masih terlalu kecil. Selanjutnya DC-Offset Adjuster untuk menghilangkan tegangan DC, karena photodiode tidak hanya menerima cahaya dari HBLED melainkan sumber DC dari cahaya lain/ambient light yang mana harus dihilangkan karena berpotensi menyebabkan cacat sinyal karena dampak saturasi OP-AMP pada AFE receiver [16-18]. Blok berikutnya adalah filter analog untuk mengkompensasi gangguan dari incandescent dan fluorescent [19].

Blok automatic gain controller (AGC) difungsikan agar sistem VLC memiliki mobilitas yang memadahi sebagaimana fungsi komunikasi nirkabel, artinya tetap berfungsi dengan baik ketika jarak kanal optik dan sudut orientasi penerimaan divariasikan [20] dan terakhir adalah analog signal amplitude adjuster yang merupakan rangkaian komparator hysteresis untuk mengkondisikan agar tegangan input ke mikrokontroller STM32F4 dalam form sinyal digital dari level tegangan $0-3,3 \mathrm{~V}_{\mathrm{DC}}$.

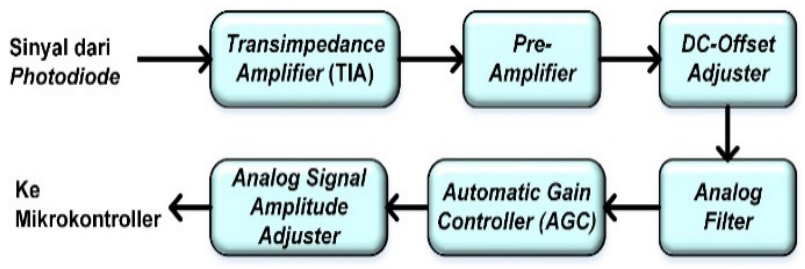

Gambar 6: Blok AFE receiver
Terdapat dua bentuk evaluasi yakni yang dilakukan, yakni demonstrasi dan pengukuran bit-error rate (BER). Demonstrasi bertujuan untuk mengetahui fungsionalitas dari performa sistem VLC yang telah dirancang. Sedangkan pengukuran BER untuk mengukur tingkat kehandalan sistem secara kuantitatif dengan pengubahan sudut orientasi modul client terhadap coordinator. Pengukuran dilakukan untuk mengirim data secara point- to-point melalui perangkat PC.

\section{HASIL DAN ANALISIS}

\section{A. Implementasi Sistem}

Gambar 7 adalah prototip modul VLC coordinator yang merupakan realisasi hardware dari Gambar 2(a). Modul terdiri atas board mikrokontroller STM32F4, AFE transmitter dan HBLED Coo Chip LEDMDW110C. Modul ini berfungsi sebagai pengirim informasi ke $V L C$ client (Gambar 8) melalui medium cahaya tampak.

Prototip VLC client terdiri atas board mikrokontroller STM32F4, photodiode SP-8ML, dan AFE receiver. Modul ini berfungsi sebagai penerima informasi dari VLC coordinator, kemudian data-data yang diterima akan ditampilkan pada PC melalui koneksi via USB. Sedangkan GUI dibangun menggunakan program Delphi 7.0 version.

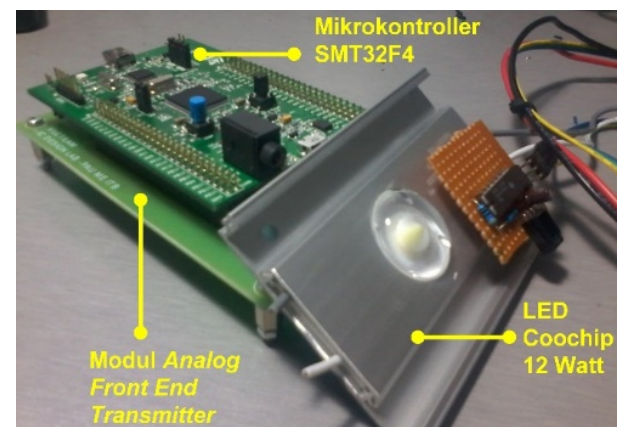

Gambar 7: Modul VLC coordinator

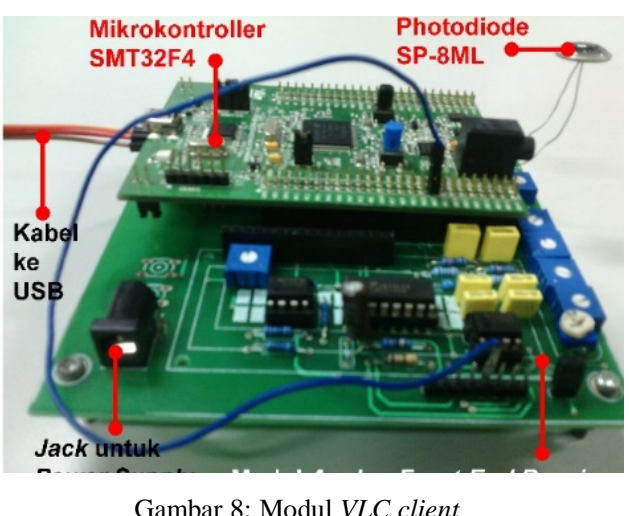

Gambar 8: Modul VLC client

\section{B. Demonstrasi Streaming Pengiriman Teks}

Adapun skenario demonstrasi sistem mengacu pada Gambar 2, yakni VLC client dihadapkan langsung ke $V L C$ coordinator selama proses streaming data berlangsung dalam jarak $30 \mathrm{~cm}$. HBLED diatur dengan 
daya maksimum 9 Watt dan tanpa pemakaian lensa pemfokus serta lensa warna ada bagian VLC client. Konten yang dikirim adalah berupa teks dari PC koordinator ke PC client lewat cahaya tampak. Berdasarkan hasil pembuktian kinerja, sistem VLC yang dirancang dapat berfungsi sesuai ekspektasi yakni mampu mentransmisikan konten teks secara real-time bahkan dalam keadaan ekstrim (didekatkan dengan lampu pengganggu fluorescent atau lampu neon).

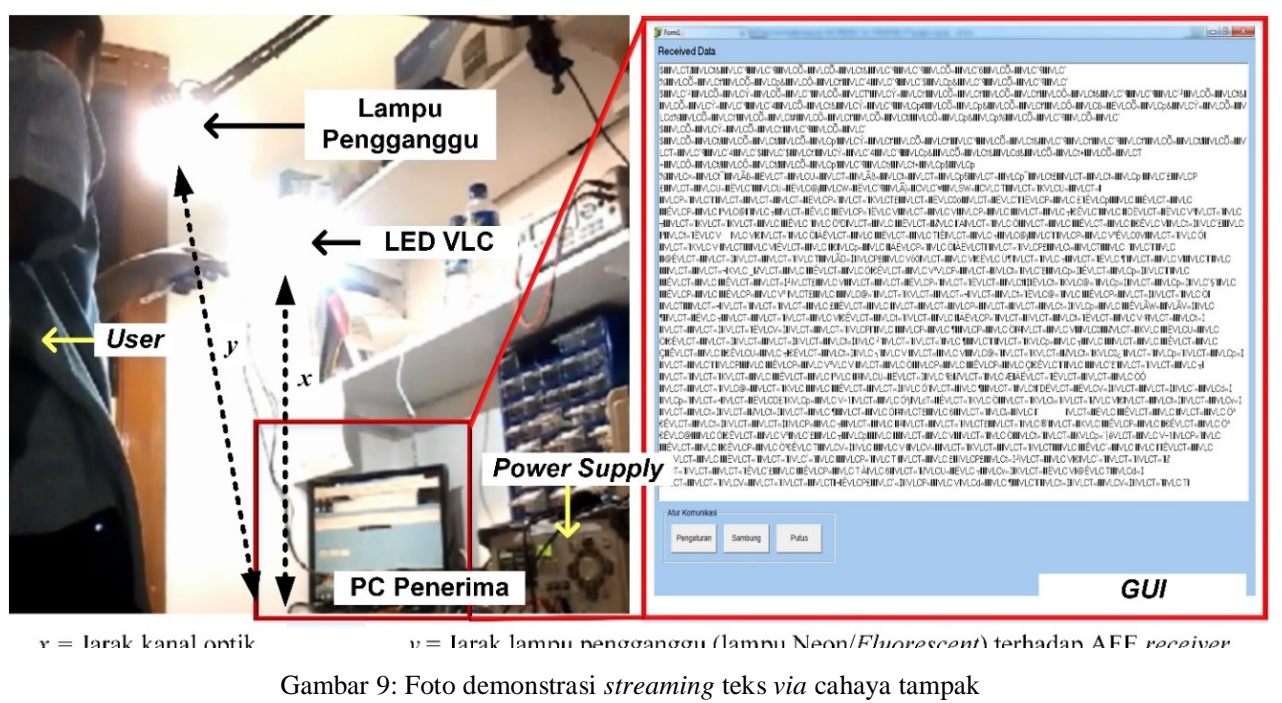

\section{Pengujian BER}

Untuk mengetahui profil BER, berikut merupakan setup eksperimen yang dilakukan: 1) Kondisi ruangan 0 lux; 2) jarak kanal optik divariasikan yakni: $30 \mathrm{~cm}, 50 \mathrm{~cm}, 70 \mathrm{~cm}, 90$ $\mathrm{cm}, 110 \mathrm{~cm}, 130 \mathrm{~cm}$, dan $150 \mathrm{~cm}$ dengan sudut $0^{\circ}$. Sementara pengubahan orientasi sudut dilakukan pada jarak tetap $60 \mathrm{~cm}$ dengan $0^{\circ}, 5^{\circ}, 10^{\circ}, 30^{\circ}, 40^{\circ}$, dan $50^{\circ}$; 3) Perhitungan BER dengan mengirimkan teks sebanyak $10 \mathrm{~kb}$ dari PC coordinator ke PC client dengan modulasi 1-PWM.

Perhitungan BER untuk pengujian sistem VLC ini adalah dengan membandingkan data yang terkirim (transmitted data) dengan data yang diterima (received data) seperti yang ditunjukkan pada persamaan (4).

$$
B E R=\frac{\text { Data diterima }}{\text { Data terkirim }}
$$

Dengan demikian, semakin nilai BER mendekati satu $(\mathrm{BER}=1)$ maka potensi error data yang diterima akan semakin besar. Dapat diperhatikan pada Tabel II bahwa ketika pada jarak $30 \mathrm{~cm}$ data tidak diterima sama sekali, karena level iluminansi yang diterima oleh photodiode besar yang mengakibatkan sinyal output dari rangkaian TIA saturasi atau sinyal informasi cacat karena terpotong. Begitu pula sebaliknya, semakin jauh jarak kanal optik maka data akan semakin memiliki nilai error yang besar atau tidak diterima sama sekali karena level iluminansi yang diterima oleh photodiode semakin lemah.

Angga Pradana: Disain dan Implementasi sistem... 2503-2372
TABEL III

PENGARUH BER TERHADAP PENGATURAN GAIN A

\begin{tabular}{|c|c|}
\hline Jarak & BER 1-PWM \\
\hline 30 & 1 \\
\hline 50 & 0,004 \\
\hline 70 & 0,0005 \\
\hline 90 & 0,001 \\
\hline 110 & 0,005 \\
\hline 130 & 0,04 \\
\hline 150 & 1 \\
\hline
\end{tabular}

Selanjutnya dilakukan pengaturan gain pada bagian AFE receiver untuk menyesuaikan level iluminansi dari HBLED. Tabel III menunjukkan bahwa gain mempengaruhi kinerja sistem/menurunkan nilai BER dan mengkompensasi efek kanal optik yang terlalu dekat.

Hasil pengamatan dengan pengaturan gain B pada sudut $0^{\circ}$ ini menunjukkan bahwa jarak ideal untuk sistem VLC yang dirancang adalah $50-70 \mathrm{~cm}$. Tabel IV merupakan hasil pengujian ketika sudut penerimaan terhadap HBLED diubahubah, dari data tersebut dapat disimpulkan bahwa sistem VLC mampu dimobilisasi dengan baik sampai sudut $50^{\circ}$ dengan jarak kanal optik $60 \mathrm{~cm}$.

TABEL IIIII

PENGARUH BER TERHADAP PENGATURAN GAIN B

\begin{tabular}{|c|c|}
\hline Jarak & BER 1-PWM \\
\hline 20 & 0,00056 \\
\hline
\end{tabular}

p-ISSN:1693-2951; e-ISSN: 


\begin{tabular}{|c|c|}
\hline 30 & 0,00089 \\
\hline 40 & 0,0012 \\
\hline 50 & 0,0025 \\
\hline 60 & 0,007 \\
\hline 70 & 0,1 \\
\hline
\end{tabular}

TABEL IVV

PENGARUH BER TERHADAP PENGUBAHAN SUDUT

\begin{tabular}{|c|c|}
\hline Sudut Penerimaan & BER 1-PWM \\
\hline $0^{\circ}$ & 0,0005 \\
\hline $5^{\circ}$ & 0,002 \\
\hline $10^{\circ}$ & 0,004 \\
\hline $30^{\circ}$ & 0,012 \\
\hline $40^{\circ}$ & 0,025 \\
\hline $50^{\circ}$ & 0,1 \\
\hline
\end{tabular}

Laju kecepatan data maksimum yang diperoleh sistem VLC dengan menggunakan modulasi 1-PWM ini adalah 3300 bps. Dengan bitrate tersebut, maka sistem VLC hanya cukup untuk mengirimkan karakter atau teks dan belum mampu dipergunakan untuk mengirimkan video berkualitas high definition (HD). Hal ini karena penulis menggunakan general OP-AMP 741 sebagai analog signal processing disemua sistem dimana tipikal bandwidth product dari OP-AMP jenis ini adalah maksimal $1 \mathrm{MHz}$.

\section{KESIMPULAN}

Sumber cahaya LED warna putih dapat dimanfaatkan untuk sistem VLC yang mana LED warna putih tersebut telah banyak digunakan sebagai infrastruktur penerangan yang ada saat ini. Dengan demikian, LED pada lingkungan indoor tersebut dapat berfungsi ganda yakni illumination sekaligus communication tanpa mengurangi fungsi utama dari LED itu sendiri sebagai penerangan. Penelitian ini mengimplementasikan sistem VLC untuk downlink dengan menggunakan modulasi 1-PWM. Perangkat DSP yang digunakan berbasis mikrokontroller menggunakan development board STM32F4. Pemilihan modulasi PWM adalah mampu membawa lebih banyak bit dalam satu pulsa dibandingkan dengan OOK serta memberikan akses komunikasi tanpa menimbulkan efek peredupan level ilumninansi (dimming) dan kedipan lampu LED secara simultan (flickering/blinking). Hasil pengujian menunjukkan bahwa sistem dapat melakukan streaming teks secara realtime. Jarak kanal optik optimum adalah $50 \mathrm{~cm}$ sampai $70 \mathrm{~cm}$ pada sudut $0^{\circ}$. Rendahnya bit-rate yang didapatkan, yakni 3,3 kbps, karena salah satu penyebabnya adalah komponen elektronik pada AFE transceiver yang menggunakan general OP-AMP. Meskipun demikian, target realisasi infrastruktur VLC yang low-cost dapat dikejar dalam penelitian ini.

Untuk mendapatkan laju kecepatan data lebih tinggi, diperlukan pemilihan DSP yang lebih baik, dalam hal ini dapat menerapkan board FPGA pada sistem VLC. Kemudian komponen-komponen elektronika yang dipilih untuk AFE transceiver harus memiliki karaktersitik/spesifikasi khusus, terutama transistor dan OP-AMP, serta diperlukan skema modulasi yang membawa lebih banyak bit dibandingkan 1PWM, dalam hal ini bisa merealisasikan 2-PWM.

\section{UCAPAN TERIMA KASIH}

Penelitian ini dibiayai oleh dana Hibah Penelitian dari KEMRISTEKDIKTI melalui skema Kerjasama Luar Negeri (KLN) kolaborasi dengan Pukyong National University-Korea Selatan, judul proyek penelitian "Machine to machine communication (M2M) based on visible light communication (VLC)" (No. Kontrak: 009/SP2H/LT/DRPM/IV/2017).

\section{REFERENSI}

[1] D. Karunatilaka, F. Zafar, V. Kalavally, "LED Based Indoor Visible Light Communications: State of the Art," IEEE Communication Surveys \& Tutorials, Vol. 17(3), pp. 1649-1678, 2015.

[2] A.A.E. Paramita, G. Sukadarmika, and P.K. Sudiarta, "Analisis kualitas jaringan lokal akses fiber optic pada Indihome PT. Telkom di area Jimbaran,” J. Teknologi Elektro, Vol. 16(1), pp. 1-5, 2017.

[3] I.P.G.Y. Pratama, G. Sukadarmika, and P.K. Sudiarta, "Perancangan jaringan fiber to the home (FTTH) menggunakan teknologi gigabyte passive optical network (GPON) pada mall park23 Tuban," J. Teknologi Elektro, Vol. 16(2), pp. 60-65, 2017.

[4] M. Figueiredo, L.N. Alves, and C. Ribeiro, "Lighting the Wireless World," IEEE Consumer Electronics Magazine, pp. 28-37, October 2017.

[5] T. Adiono, S. Fuada, and S. Harimurti, "Bandwidth Budget Analysis for Visible Light Communication Systems utilizing Commercially Available Components," Proc. of the $10^{\text {th }}$ Int. Conf. on Electrical and Electronics Engineering (ELECO), pp. 1375-1380, December 2017.

[6] S. Fuada, A.P. Putra, and T. Adiono, "Analysis of Received Power Characteristics of Commercial Photodiodes in Indoor LoS Channel Visible Light Communication," Int. J. of Advanced Computer Science and Applications (IJACSA), Vol. 8(7), pp. 164-172, July 2017. DOI: 10.14569/IJACSA.2017.080722.

[7] S. Fuada, "Kajian Aspek Security pada Jaringan Informasi dan Komunikasi Berbasis Visible Light Communication," J. INFOTEL, Vol. 9(1), pp. 108-121, August $2017 . \quad$ DOI: https://doi.org/10.20895/infotel.v9i1.163.

[8] S. Rajagopal, R.D. Roberts, and S-K. Lim, "IEEE 802.15.7 Visible Light Communication: Modulation Schemes and Dimming Support," IEEE Communications Magazine, March 2012.

[9] A. Pradana, "Rancang Bangun Layer Fisik Komunikasi Cahaya Tampak Berbasis DC-OFDM dan PWM," Master Thesis, ITB, Indonesia, 2016.

[10] A. Pradana, et al., "VLC Physical Layer Design based on Pulse Position Modulation (PPM) for Stable Illumination," Int. Symp. on Intellegent Signal Processing and Communication Systems (ISPACS), pp. 368-373, November 2015.

[11] STM32F4 Series, "STM32F4 series of high-performance MCUs with DSP and FPU instructions. [Online] http://www.st.com/en/microcontrollers/stm32f4series.html?querycriteria $=$ productId $=$ SS1577

[12] S. Fuada, T. Adiono, A. P. Putra, and Y. Aska, "A Low-cost Analog Front-End (AFE) Transmitter Designs for OFDM Visible Light Communications," Proc. of the IEEE Int. Symposium on Electronics and Smart Devices (ISESD), pp. 371-375, October 2016. DOI: 10.1109/ISESD.2016.7886750.

[13] S. Fuada, and T. Adiono, "Rancang Bangun Layer Fisik Visible Light Communication Pada Sistem Transmisi Audio," J. INFOTEL, Vol. 9(3), pp. 352-360, August 2017. DOI: https://doi.org/10.20895/infotel.v9i3.288.

[14] T. Adiono, S. Fuada, A.P. Putra, and Y. Aska, "Desain Awal Analog Front-End Optical Transceiver untuk aplikasi Visible Light Communication," J. Nasional Teknik Elektro dan Teknologi Informasi (JNTETI), Vol. 5(4), pp. 319-327, November 2016. DOI: 10.22146/jnteti.v5i4.280.

[15] S. Fuada, A.P. Putra, Y. Aska, and T. Adiono, "Trans-impedance Amplifier (TIA) Design for Visible Light Communication (VLC) using Commercially Available OP-AMP," Proc. of the $3^{\text {rd }}$ Int. Conf. on 
ajalah Ilmiah Teknologi Elektro, Vol. 17, No. 2,Mei - Agustus 2018

DOI: https://doi.org/10.24843/MITE.2018.v17i02.P11

Information Tech. Computer, and Electrical Engineering (ICITACEE), pp. 31-35, October 2016. DOI: 10.1109/ICITACEE.2016.7892405.

[16] S. Fuada, A.P. Putra, Y. Aska and T. Adiono, "A First Approach to Design Mobility Function and Noise Filter in VLC System Utilizing Low-cost Analog Circuits," Int. J. of Recent Contributions from Engineering, Science, and IT (iJES), Vol. 5(2), pp. 14 - 30, 2017. DOI: 10.3991/ijes.v5i2.6700

[17] T. Adiono, and S. Fuada, "Investigation of Optical Interference Noise Characteristics in Visible Light Communication System," Proc. of the 2017 Int. Symp. on Nonlinear Theory and Its Applications (NOLTA), pp. 612-615, December 2017.

[18] T. Adiono, and S. Fuada, "Investigation of Optical Interference Noise Characteristics in Visible Light Communication System," Proc. of the 2017 Int. Symp. on Nonlinear Theory and Its Applications (NOLTA), pp. 612-615, December 2017.

[19] T. Adiono, A. Pradana, R.V.W. Putra, and S. Fuada, "Analog Filter Design in VLC Analog Front-End Receiver for Reducing Indoor Ambient Light Noise," Proc. of the IEEE Asia Pacific Conf. on Circuit and Systems (APCCAS), pp. 581-584, October 2016. DOI: 10.1109/APCCAS.2016.7804058.

[20] S. Fuada, R.A. Saputro, and T. Adiono, "Automatic Gain Control Circuit for Mobility Visible Light Communication System using LM13700" Proc. of the IEEE Int. Symposium on Electronics and Smart Devices (ISESD), Yogyakarta, Indonesia, October 2017.

\section{LAMPIRAN}

Source code untuk fungsi encoding 1-PWM

\section{unsigned int fungsi_1PWM(char data_PWM) \{}

unsigned int pwm0, pwm1;

if (PWM_speed $==3$ ) \{

pwm0 $=1500 ;$ pwm1 $=900$;

\}

else if (PWM_speed $==2$ )

pwm $0=550 ;$ pwm1 $=320$

\}

else if (PWM_speed $==1$ )

pwm0 $=170 ;$ pwm1 $=100 ;$

\} ;

if (data_PWM $==0$ )

return pwm0;

else if (data_PWM $==1$ ) \{

return pwm1

\}

void modulasi 1PWM (char data PWM) \{

char data_buffer[9];

unsigned int PWM1_termodulasi[9];

unsigned char indeks;

unsigned int space, header, stop;

if (PWM_speed $==3$ ) \{

space $=800 ;$ header $=2000$, stop $=2500$;

//speed 3

else if (PWM_speed $==2$ )

space $=250 ;$ header $=780$, stop $=1000$; //speed 2

else if (PWM_speed $==1$ )

space $=150 ;$ header $=250$, stop $=360 ;$

/ / speed 1

\} ;

data_buffer [1] = data_PWM \& $0 \times 01$

data_buffer[2] $=($ data_PWM $>>1) \& 0 \times 01$;

data_buffer $[3]=($ data_PWM $>>2) \& 0 \times 01$;

Angga Pradana: Disain dan Implementasi sistem... data buffer [4] = (data PWM $>>3$ ) \& $0 \times 01$

data_buffer[5] $=($ data_PWM $>>4) \& 0 \times 01$;

data_buffer[6] $=($ data_PWM $>>5) \& 0 \times 01$;

data_buffer $[7]=($ data_PWM $>>6) \& 0 \times 01$;

data_buffer $[8]=($ data_PWM $>>7) \& 0 \times 01$;

for (indeks=1; indeks $<9$; indeks ++ ) \{

PWM1_termodulasi[indeks] =

fungsi_1PWM(data_buffer[indeks]) ; \} ;

//--------------transmisi data PWM-

GPIO_WriteBit(GPIOA, GPIO_Pin_4,0) ;

Delay (space); //SPACE

GPIO_WriteBit(GPIOA, GPIO_Pin_4,1) ;

Delay (header); //PWM HEADER

GPIO_WriteBit (GPIOA, GPIO_Pin_4,0) ;

Delay (space); //SPACE

for ( indeks $=1$; indeks $<9$; indeks ++ ) \{

GPIO_WriteBit(GPIOA, GPIO_Pin_4, 1) ;

Delay (PWM1_termodulasi [indeks]);

GPIO_WriteBit(GPIOA, GPIO_Pin_4,0) ;

Delay (space)

\};

GPIO_WriteBit(GPIOA,GPIO_Pin_4,0) ;

Delay (space);

GPIO_WriteBit(GPIOA, GPIO_Pin_4, 1);

Delay (stop);

GPIO_WriteBit(GPIOA, GPIO_Pin_4,0) ;

Delay (space);

GPIO_WriteBit(GPIOA, GPIO_Pin_4, 1) ;

Source code untuk Fungsi decoding 1-PWM

unsigned char fungsi_decoder_1PWM(uint16 t pulse) \{

uint16_t bit0_atas,

bit0_bawah,bit1_atas,bit1_bawah;

//bit0_atas $=7000$; bit0_bawah $=5700$;

//speed 1

/ / bit1_atas $=4500 ;$ bit1 bawah $=2800$;

bit0_atas $=750$; bit0_bawah $=575 ; / /$ speed

bit1_atas $=490 ;$ bit1_bawah $=280$;

if ((pulse >= bit0_bawah) \&\& (pulse $<=$ bito_atas) ) \{

return 0 ;

\};

if ((pulse >= bit1_bawah) \&\& (pulse $<=$ bit 1 atas) $)\{$

return 1;

\} ;

char decoder 1PWM (uint16 t data mentah [40]) ( unsigned char buffer[9];

char data_diterima;

for (indeks $=1$; indeks $<9$; indeks ++ ) \{

buffer [indeks] =

fungsi decoder_1PWM (data mentah [indeks]);

data_diterima $=$ buffer[1] + buffer[2]*2 + buffer [3]*4+buffer[4]*8+buffer[5]*16+ buffer $[6] * 32+\operatorname{buffer}[7] * 64+$

buffer [8]*128;

return data_diterima;

p-ISSN:1693 - 2951; e-ISSN: 2503-2372 
[Halaman ini sengaja dikosongkan ] 